\title{
敷砂上の落石の衝撃加速度と衝撃土圧に関する実験的研究

\author{
EXPERIMENTAL STUDY OF IMPULSIVE ACCELERATION AND EARTH PRESSURE \\ BY FALLING ROCKS ON A SAND LAYER
}

\author{
吉田 博*・栘谷 浩**・鈴木哲次*** \\ By Hiroshi YOSHIDA, Hiroshi MASUYA and Tetsuij SUZUKI
}

\begin{abstract}
For a rational estimation of the design impulsive load to rock fall protection structures due to rock falls, a test set-up with a tower of $24.8 \mathrm{~m}$ height for the rock fall experiments has been constructed.

Using this test set-up, the impulsive accelerations of weights simulating falling rocks and the impulsive earth pressure through a sand layer which acts to the rock fall protection structures are experimentally measured. The effects of the weights, shapes and falling heights of the falling rocks to the impulsive acceleration and the earth pressure are investigated.
\end{abstract}

\section{1. まえがき}

わが国は狭小なうえに山間部が多く, 道路の建設もや むなく山岳地帯を選ばねばならないケースが多く,また， 既存の道路の整備に伴い, 道路交通の安全確保の上から も道路を落石から保護する必要性がますます増大してい る.

第 9 次道路整備五箇年計画が昭和 58 年度に発足し, その目標とする 21 世紀をめざした道路作りの第一に, 交通安全と防災の確保をめざした道路交通が挙げられて いる.この第 9 次道路整備五箇年計画の発足により，今 後, 落石防護工としての落石覆いが多数建設されるよう になるものと思われる.

しかし，これまで建設された多くの落石覆いの計画・ 設計における荷重および構造の選択は, 現場の状況より 判断して, その都度経験工学的に決定されているのが現 状のようである.このような経験工学的な方法より脱し， 理論あるいは実験に基づく合理的な解析が望まれてきた が，比較的地形，地質条件に恵まれている欧米諸国には

* 正会員 工博 金沢大学教授 I学部土木工学科 ( (920 金沢市小立野 2-40-20)

** 正会員 工修 金沢大学助手 工学部土木工学科 (同上)

*** 正会員 工修 愛知県技師 企業庁三河港工事事務所
参考となるデータにそしく，わが国においても落石防護 施設に関する調查報告書 ${ }^{1 / 21}$, 手引 ${ }^{31}$, 便覧 4 (1) 等がある ものの, 落石覆い上への落石による衝撃力に関しては, わずかな研究が発表されているに過ぎない(6) 13).

落石が落石覆いに及ぼす衝撃力に関する因子として, 落石質量, 落下高さ, 斜面の形状および勾配, 落石の形 状および岩質，サンドクッション材の厚さおよびその諸 性質, 落石覆いの構造形式等が考えられる.

本研究においては, 落石がサンドクッション上に鉛直 落下する場合の衝撃加速度およびサンドクッション中を 伝播し，落石覆い構造物に及ぼす衝撃土圧およびその分 布について, 落石の質量および形状, 落下高さを変化さ せた数多くの実験結果より検討を行った。

\section{2. 実験方法}

\section{（1）実験用設備および装置}

石川県能美郡辰口町地内の金沢大学辰口団地内に落石 実験場を建設した：実験場には，送電用の鉄塔の上部を 切断して取り除いた高さ $24.8 \mathrm{~m}$, 底部幅 $7.4 \mathrm{~m} \times 6.25$ $\mathrm{m}$ の落石実験用鉄塔を建設した。鉄塔最上部には，最 大容量 5.0 tのホイストクレーンを取り付けた. 鉄塔脚 内部は，まず，厚さ $20 \mathrm{~cm}$ で栗石を敷きつめ，その上 に直交 2 方向に配筋し, 厚さ $30 \mathrm{~cm}$ のコンクリートを 
Table 1 Properties of used sand.

\begin{tabular}{|c|c|c|c|}
\hline 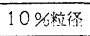 & $60 \%$ 經徍 & 均筫标数 & 曲率保楼 \\
\hline$D_{12}(m u)$ & $D_{601}(\mathrm{~mm})$ & $U_{c}$ & u \\
\hline 0.09 & 0.14 & 1.56 & 0.10 \\
\hline
\end{tabular}

幅 $6 \mathrm{~m} \times 6 \mathrm{~m}$ の範囲で打設した。このコンクリートスラ ブ上に鋼製形枠を組み立て，幅 $5 \mathrm{~m} \times 5 \mathrm{~m}$ ，高さ $1.5 \mathrm{~m}$ の土槽を製作した．落石覆いに使用されるサンドクッ ション材としては,一般に, いわゆる, 川砂, 海砂, 山砂, 砕砂等が用いられるが, 本実験では, 一般に現場で最も 容易に採取が可能であると考えられる，山砂を用いた。 その主な特性を Table 1 に, また, その粒径加積曲線を

Fig. 1 に示す.

前述のとおり, 落石の衝撃力に及ぼす因子は非常に多 いが, 落石自身に起因するものは, 落石の質量およびそ の形状である. 落石の質量とその形状を考慮した 7 種の 重鍾を製作した。まず，質量は $300 \mathrm{~kg}, 1000 \mathrm{~kg}$ および $3000 \mathrm{~kg}$ の 3 種とし, 形状はいずれも円筒状であるが, 質量が $300 \mathrm{~kg}$ および $1000 \mathrm{~kg}$ のもについては，その 底面の形状の影響を調べるために底面が球面の一部を成 すもの (以下, 球底という), 底面が円錐形のもの (以下, 錐底という) および底面が平面のもの(以下, 平底という) の 3 種ずっ, 計 6 種とした。 また, 質量が $3000 \mathrm{~kg}$ の ものは球底のみとした．重錘は鋼殻にコンクリートを充 填して所定の質量となるように製作した。なお，コンク リート充填部分の高さと直径の比をほぼ 1.0 となるよう にし, また, 重錘の重心位置での衝撃加速度が測定でき るように, $300 \mathrm{~kg}$ および $1000 \mathrm{~kg}$ の重錘には直径 20 $\mathrm{cm}$ の円筒を埋め込み, その底面に加速度計を取り付け られるようにした. 用いた 7 種の重錘の形状および寸法 をFig. 2 に示す.

重鍾を容易にかつ安全に落下させることができるよう に，電気的自動落下装置を開発した，詳細は文献 13) を参照されたい.

\section{（2）測定項目および測定方法}

\section{a ) 衝撃加速度}

重錘を所定の高さまで吊り上げ，電気的自動落下装置

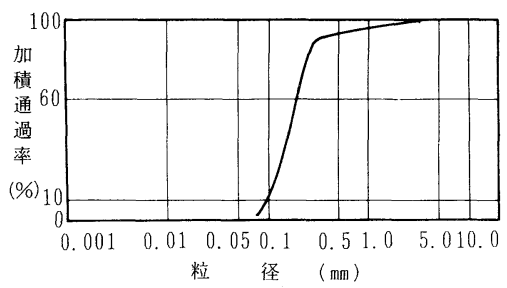

Fig. 1 Particle size accumulation curve.
を作動させて初速度零で鉛直自由落下させ，重錘がサン ドクッションに衝突し静止するまでの重錘の衝撃加速度 を測定した．重錘が傾斜して落下する場合も考えて，重 鍾の重心位置に 3 方向加速度計（容量 $500 \mathrm{~g}$ ) をボルト 締めして固定し，直交する 3 方向の加速度（鉛直成分お よび水平直交 2 成分）を測定した。

加速度計で測定する衝撃加速度はリード線による損失 を少なくするため, 重錘に取り付けた加速度用増幅器で 増幅した後リード線を通して後述する 2 種の方法で同時 に2 台のマイクロコンピューターに入力し, A/D 変換 を行い，数值データをカセットテープに記録すると同時 に最大衝撃加速度等をただちに計算し，これらの計算結 果と波形をディスプレイ上にグラフィック出力させて， 実験結果の観察を行い, 各種データをプリンターに出力 した.

$\mathrm{A} / \mathrm{D}$ 変換は 2 種の方法で行った. 一つは, 加速度計 の高周波成分も含めた出力を直接マイクロコンピュー ター（TEAC 社製， PS 80) に入力し, $2000 \mathrm{~Hz}$ のサン プリング速度で 2 秒間, デー夕数 4000 で A/D 変換を 行った. 以後, このサンプリング方式を高速サンプリン グとよぶことにする．他は，加速度計の出力の高周波成 分を除去するために，加速度計の出力を $200 \mathrm{~Hz}$ のロー パスフィルターを通してマイクロコンピューター (TEAC 社製, $\mathrm{PS} 85$ ) に入力し, $600 \mathrm{~Hz}$ のサンプリ ング速度で 2 秒間, データ数 1200 でA/D 変換を行っ た. 以後, このサンプリング方式を低速サンプリングと よぶことにする.

b) 土 王

土槽の中心から $15 \mathrm{~cm}$ または $30 \mathrm{~cm}$ の間隔で 5 また は 6 個の土圧計を配置した。土圧計は土の動きによるず れを防ぐために，鋼製の保持装置にはめ込み，周囲を石
$300 \mathrm{~kg}$

球

底

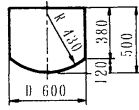

錐

底

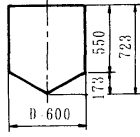

平

底

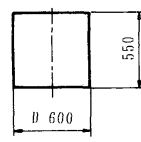

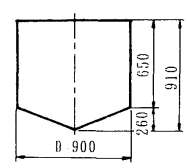

$1000 \mathrm{~kg}$
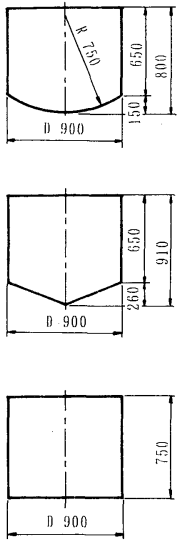

$3000 \mathrm{~kg}$

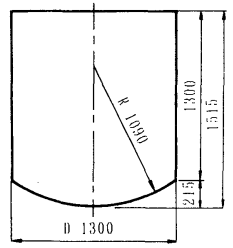

(単位mm)
Fig. 2 Shapes and dimensions of weights. 
膏で固めた。土圧の測定は動ひずみ測定器を介してマイ クロコンピューター ( TEAC 社製, PS 85) に入力し, $600 \mathrm{~Hz}$ のサンプリング速度で, 加速度の低速サンプリ ングと同時に，2 秒間，デー夕数 1200 で A/D 変換を 行い，数值データをカセットテープに記録すると同時に 最大土玨等をただちに計算し，これらの計算結果と波形 をディスプレイ上にグラフィック出力させて, 実験結果 の観察を行い, 各種データをプリンターに出力した.

c）落下位置

落下した重錘の中心の座標を，あらかじめ土槽内に定 めた $x-y$ 座標系により $\mathrm{cm}$ 単位で測定した。

d）貫 入 量

重鍾が落下したとき, 落下以前のサンドクッション表 面より計測した重鍾底面中心 (以後, 落下点中心という) の沈下量を, 重鍾の貫入量とした.

e）含水比および密度

サンドクッションの状態を調べるために, 1 日 1 回, 最 初のサンドクッション製作時にコンクリートスラブ上部

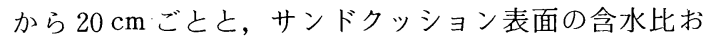
よび密度の測定を行った。密度は直径 $10 \mathrm{~cm}$, 高さ $5 \mathrm{~cm}$ のステンレス製の円筒を用いて採取を行い測定した.

f）コーン支持力

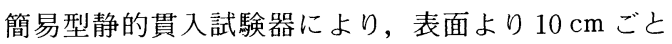
に測定したサンドクッション材の平均貫入抵抗力をコー ンの断面積で除したものであり，本実験ではサンドクッ ション材の締め固めの程度または貫入抵抗の程度を表わ す指標として用いる.

なお，本実験で用いた実験設備と計測システムを Fig. 3 に示す.

\section{（3）実験方法}

本実験では，コンクリートスラブ上に土槽を設け，そ

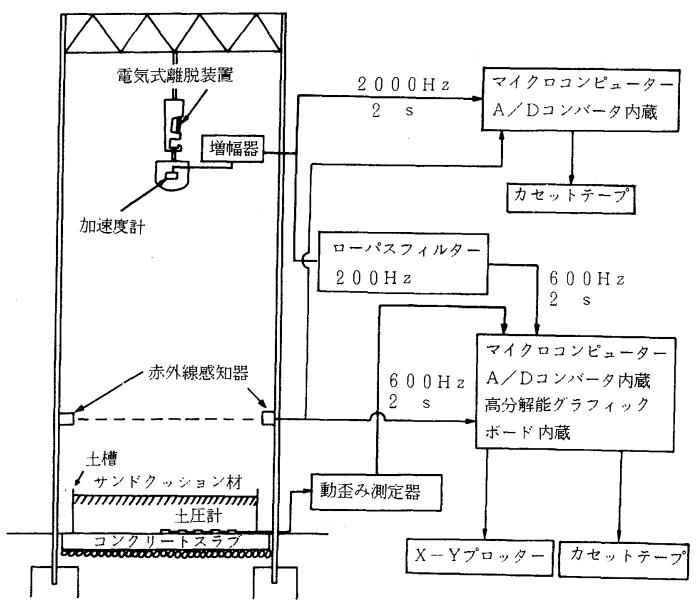

Fig. 3 Test set-up and measuring system.
の中にサンドクッション材を敷き，鉄塔に取り付けた電 気ホイストクレーンにより各種の重錘を吊り上げ, 5,10 , 15 および $20 \mathrm{~m}$ の各高さから自由落下させた.

実験は以下の順序で行った。

a) サンドクッションの製作

サンドクッションの厚さは, $300 \mathrm{~kg}$ および $1000 \mathrm{~kg}$ の重鍾に対しては $90 \mathrm{~cm}, 3000 \mathrm{~kg}$ の重錘に対しては $120 \mathrm{~cm}$ とした。これは, 文献 6),7）によると，これ以 上のサンドクッション厚に対して, 緩衝効果の増大が期 待できないことが明らかにされているからである.

サンドクッションの製作は以下の 2 通りの方法で行っ た。

掘り返し状態——サンドクッションをコンクリートス ラブ上面まで掘り返し， $20 \mathrm{~cm}$ 厚ずつサンドクッション 材を投入して足踏みにより締め固め, サンドクッション 厚が $90 \mathrm{~cm}$ の場合，最後の表面は $10 \mathrm{~cm}$ 厚で同様に締 め固めるもの.

自然状態一一重錘の落下後, 重鍾によりできたくぼみ の表面およびその周辺をほぐしながら $20 \mathrm{~cm}$ 厚ずつ埋 め戻し, 足踏みにより締め固め, 最後に表面を同様に締 め固めるもの.

実験は, 最初, 掘り返し状態で行い, その後, 自然状 態で 2 3 回行った後, 再び掘り返し状態とした.

b ） サンドクッション材の含水比および密度の測定

c ） 落下前のサンドクッションのコーン支持力の測 定

d）衝撃加速度（低速および高速サンプリング）お よび土圧の測定

サンドクッション表面上, 約 $5 \mathrm{~m}$ の鉄塔上に取り付 けた赤外線感知器に重錘が到達したときに, マイクロコ ンピューターによる衝撃加速度および土圧のサンプリン グを自動的に開始するようにした。

e ）重鍾の落下位置の測定

f ）重錘の貫入量の測定

g) 落下後のサンドクッションのコーン支持力の測 定

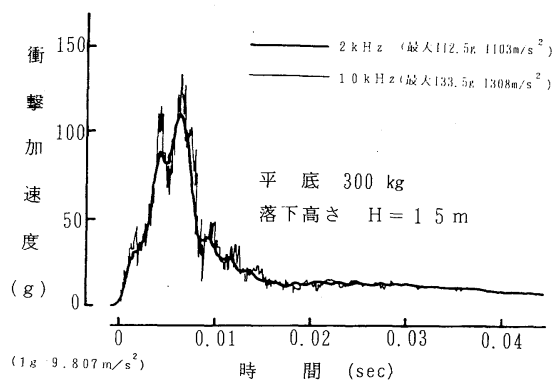

Fig. 4 Shapes of accelerations. 


\section{3. 実験結果および考察}

\section{（1）測定街和速度の波形}

測定衝撃加速度の波形は必ずしも滑らかな波形ではな く, 低い周波数成分の波の上に高周波成分が載る波形で あり，平底の重鍾においてその傾向は顥著に現われる.

Fig. 4 は, $300 \mathrm{~kg}$ の平底の重鍾を高さ $15 \mathrm{~m}$ から落下さ せたときの衝撃加速度を 2 台のマイクロコンピューター を用い $10 \mathrm{kHz}$ でサンプリングしたものと, $200 \mathrm{~Hz}$ の ローパスフィルターを通し, $2 \mathrm{kHz}$ でサンプリングした ものの波形の比較を行ったものである. $10 \mathrm{kHz}$ でサン プリングされた加速度波形を周波数分析した結果を Fig. 5 に示す.図中，破線で示されている周波数成分は， 同一の重錘の底面をハンマーで打撃したときの弾性波に よる卓越した周波数を示している.これより, 重鍾の衝 突による弾性波の周波数成分が卓越していることがわか る.したがって, 高周波成分を含めた加速度は本研究の 目的には不適当であり, 低周波成分のみのサンプリング で十分であると思われるので, 衝撃加速度は $200 \mathrm{~Hz}$ の ローパスフィルターを通し，600 Hzのサンプリングで すべての測定を行うことにした。これはまた，後述する 測定土圧の検討結果からも，妥当であると思われる。

測定された衝撃加速度の波形は，おおよそ，Fig. 6 に 示すように 4 つのパターンに分類できる. タイプ1のパ ターンは平底の重鍾にみられるものであり, 鋭い立ち上 りとピーク後の鋸菌状の減衰を有している. 夕イプ 2 の パターンは, 比較的滑らかな 1 つの単調な波形から成っ ており, 球底および錐底の重錘でサンドクッションが比 較的軟らかいときのものである. タイプ 3 およびタイプ 4 のパターンは 2 つ山を有する波形で, 夕イプ 3 は第 1 のピークが卓越しており，第 2 のピークが小さいもの で, $300 \mathrm{~kg}$ の球底および錐底の重鍾によくみられるパ ターンである.タイプ 4 は，第 1 および第 2 のピークと

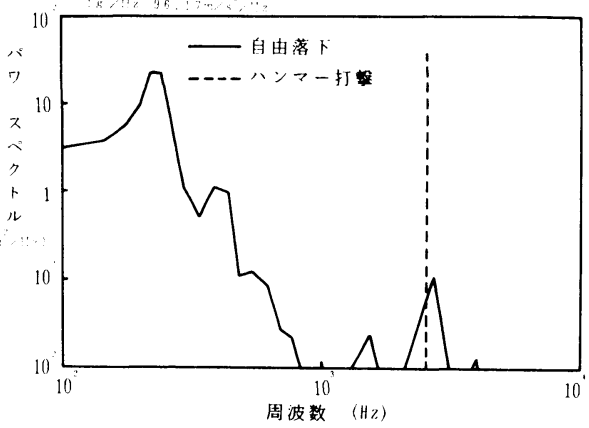

Fig. 5 Frequency analysis of impulsive acceleration (Flat bottom, $W=1000 \mathrm{~kg}, H=15 \mathrm{~m}$ ).

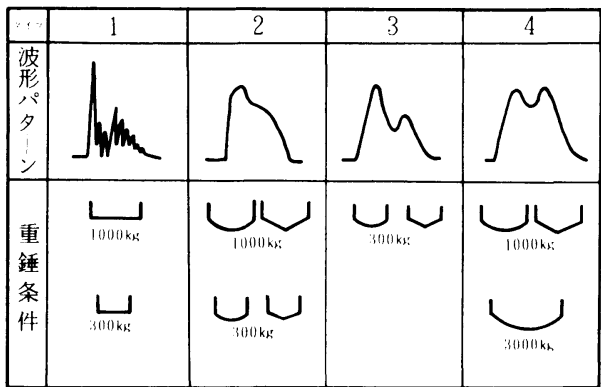

Fig. 6 Patterns of acceleration.

もほぼ同程度の大きさであり, $1000 \mathrm{~kg}$ の球底, 錐底お よび $3000 \mathrm{~kg}$ の重錘に多くみられるパターンである.

タイプ1のパターンは, 平底の重錘が平面でサンド クッションに衝突することにより，急激な立ち上りと大 きなピークを有することは理解できるが，夕イプ 3 およ

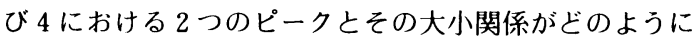
して発生するかはいまだ推論の域を脱せず, さらに研究 が必要である.

\section{（2）最大衙撃加速度}

Fig. 7 およ゙ 8 は，それぞれ，300 kgおよび $1000 \mathrm{~kg}$ の球底，錐底および平底の重鍾を， $5 \mathrm{~m}, 10 \mathrm{~m}, 15 \mathrm{~m}$ お よび $20 \mathrm{~m}$ から落下させたときの最大衝撃加速度と落下 高さの関係を示している.

それぞれ，度数分布で示されているものは球底の重鍾 に対するものであり，300 kg および $1000 \mathrm{~kg}$ の度数分布 より，実験值によく一致する確率密度関数は，対数正規 分布であると思われるので，図中にこれも示した。三角 印および四角印は，それぞれ，錐底および平底の重鍾の

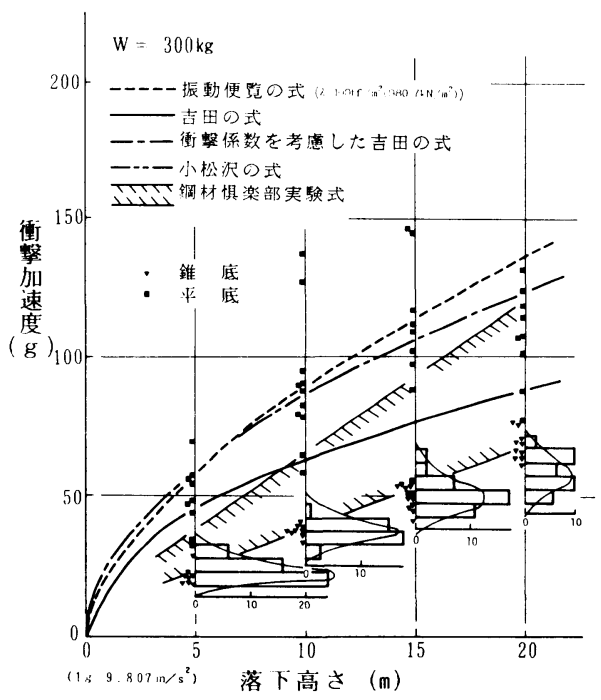

Fig. 7 Relationship between impulsive accelerations and falling heights $(300 \mathrm{~kg})$. 
実験結果を示している.

Fig.9は, $3000 \mathrm{~kg}$ の球底の重鍾を $5 \mathrm{~m}, 10 \mathrm{~m}, 15 \mathrm{~m}$, $17 \mathrm{~m}$ および $18 \mathrm{~m}$ から落下させたときの最大衝撃加速度 と落下高さの関係を示している. 実験值は, 黒丸印と度 数分布の両方で示されている.

これまで, 落石による衝撃力の推定を目的としたいく つかの理論式および実験式が提案されている(5) 8),12),14). その主なものは次のとおりである.

\section{a ）振動便覧の式 ${ }^{5}$}

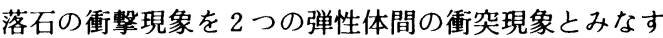
ものであり, A. E. H. Love の 2 つの弾性体が衝突する ときの物体間の圧力に関する基礎方程式より出発し,

Herz の接触論を用いている. 主な仮定としては半無限 弾性体上に密度 $2.6 \mathrm{~g} / \mathrm{cm}^{3}$ の㓮球が一定速度で衝突する ものとして, 衝撃力を求めたものである.

衝撃力 $P(\mathrm{tf})$ は,

$P=2.46 \lambda^{2 / 5} W^{2 / 3} H^{3 / 5}$

にて与えられている.ここに，入はサンドクッション材 のラーメの定数であり, 非常に軟らかい土で $\lambda=100$ $\mathrm{tf} / \mathrm{m}^{2} \quad\left(980.7 \mathrm{kN} / \mathrm{m}^{2}\right)$, 軟らかいもので $\lambda=300 \sim 500$ $\mathrm{tf} / \mathrm{m}^{2}\left(2942 \sim 4903 \mathrm{kN} / \mathrm{m}^{2}\right)$, 硬いもので $\lambda=1000 \mathrm{tf} / \mathrm{m}^{2}$ $\left(9807 \mathrm{kN} / \mathrm{m}^{2}\right)$ とされており, W は落石質量 $(\mathrm{t}), H$ は落下高さ $(\mathrm{m})$ である．落石対策便覧 ${ }^{4)}$ では，落石に よる設計衝撃力として式（1）に $\lambda=100 \mathrm{tf} / \mathrm{m}^{2}(980.7$ $\left.\mathrm{kN} / \mathrm{m}^{2}\right)$ として求めた值を用いることを推奖している.

また，落石の形状とサンドクッション厚を考虑に入れ

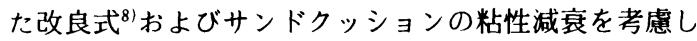
た改良式 ${ }^{(2)}$ も提案されている.

b ) 小松沢の式 ${ }^{14)}$

サンドクッション材を弾性ばねと仮定し，そのばねの 上に落石が衝突するものとして，エネルギー法を用いて 衝撃力を計算している.

$$
P=1.619 k^{1 / 4} W^{5 / 6} H^{1 / 2}
$$

ここに，kはサンドクッション材のばね定数で, 普通の 土で $k=500 \mathrm{tf} / \mathrm{m}^{3}\left(4903 \mathrm{kN} / \mathrm{m}^{3}\right)$ であるとされている.

\section{c ) 鋼材俱楽部の式 ${ }^{6 /}$}

落石による衝撃力の基本的問題点を解明するために, 落石の規模と発生する衝撃力との相関性, サンドクッ ション材の緩衝効果, 分布効果, および実物構造物を試 験し, 落石覆い全体についての落石による衝撃力と構造 力学的特性を究明することを目的とした最初の実験であ る. 重錘質量 $1000 \mathrm{~kg}$, 最大落下高さ $15 \mathrm{~m}$ で実験を行い, その結果衝撃加速度と落下高さの関係は, ある幅をもつ た直線の範井内に入るとしている.

d ） 吉田らの実験 ${ }^{71}$

$300 \mathrm{~kg}, 1000 \mathrm{~kg}$ および $3000 \mathrm{~kg}$ の重鍾を最大 $13 \mathrm{~m}$ の高さからコンクリートスラブ上および $\mathrm{PC}$ 桁上に落
下させて, 衝撃加速度の测定を行っている.この実験結 果より, 重鍾がサンドクッションに衝突してから静止す るまでの時間は落下速度にほとんど関係せず, 落石質量 のみに関係することに着目し，衝撃力は次式で表わすの がよいとしている.

$$
P=2 \alpha \frac{W}{T_{0}} \sqrt{2 g H}
$$

ここに， $\alpha$ は所定の信頼度に対する係数であり，Wは 落石質量, $H$ は落下高さ, $g$ は重力の加速度, $T_{0}$ は落 石が静止するまでの時間である.

いま山砂の場合で, $95 \%$ の信頼度について示せば,

$$
\begin{aligned}
& P=2.42 \frac{W}{g T_{0}} \sqrt{2 g H} \cdots \\
& T_{0}=0.0220 \mathrm{~W}+0.0485
\end{aligned}
$$

であるとされている.

また,実験および実験結果を用いた動的応答計算より， 実験に用いた PC 製落石覆いには，衝撃係数として 0.4 を用いることを推奖している.

Fig. 7〜9においては，上記の各種推定式が示されて いる. まず，破線は式（1）で示される振動便覧の式に， 落石対策便覧で採用されている $\lambda=100 \mathrm{tf} / \mathrm{m}^{2} \quad(980.7$ $\left.\mathrm{kN} / \mathrm{m}^{2}\right)$ を適用したものである。実線は式（4）による 吉田の式を, 一点鎖線は式（4）に設計用の衝撃係数と して 0.4 を用いたものである. 二点鎖線は式（2）の小 松沢の值であり, 斜線で井まれた範囲は鋼材俱楽部の実 験の範囲を示している.

Fig. 7〜9に示された最大衝撃加速度と落下高さの関 係より以下のことが明らかとなった。

a) 衝撃加速度は重鍾質量とともに減少する.

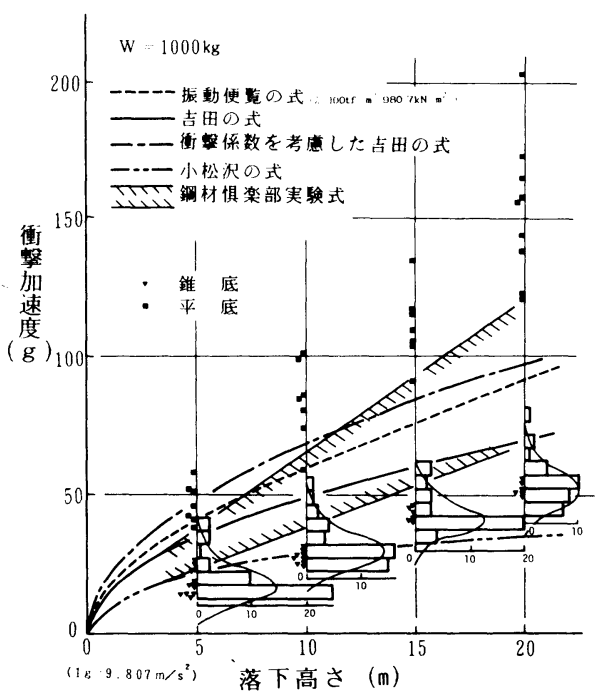

Fig. 8 Relationship between impulsive accelerations and falling heights $(1000 \mathrm{~kg})$. 
b ）錐底の重鍾の衝撃加速度は球底のものとほぼ等 しく, 画者の差異は認められない.

c ）平底の重鍾の衝撃加速度は, 球底および錐底の ものに比較して極端に大きい.

d ）吉湴の式は実験値の上限によく一致している.

e ) 振動便覧の式 $\left(\lambda=100 \mathrm{tf} / \mathrm{m}^{2}\left(980.7 \mathrm{kN} / \mathrm{m}^{2}\right)\right)$ は, 衝撃を考慮した吉用の式と全範㬰にわたってよく一致し ている.

f）小松沢の式は落石質量が小さく，落下高さも小 さい範囲では実験値の平均的な值を与えるが，落下高 さが大きい範囲では, 実験値の下限を与える.しかし, $3000 \mathrm{~kg}$ の重鍾に対する実験結果に対しては,その平均 值に一致する.

g）鋼材俱楽部の実験から得られた衝撃加速度の範 井は, 落下简さが大きい場合, 実験值の範囲より上方に 位置する。

\section{（３）衝軗加速度に及ぼすその他の因子の影䈏}

衝撃加速度に及ぼす落石以外の影響因子としてはサン ドクッション材の種類, 厚さ, 含水比, 締め固めの程度 等が考えられる. サンドクッション材の厚さが衝撃加速 度に与える影響は, 過去の研究 ${ }^{6 ! .71}$ 上り, 厚さが $60 \mathrm{~cm}$ から $90 \mathrm{~cm}$ 程度以上では衝撃加速度にほとんど変化が みられないことが明らかにされている。ここでは, 衝撃 加速度と貫入量の関係，衝撃加速度に与えるサンドクッ ションの含水比および締め固めの影響を検討する.なお， サンドクッション材の種類が衝撃加速度に与える影響の 検討は重要な課題であるが, 本研究においては, まだ検 討しておらず，さらに研究が必要である.

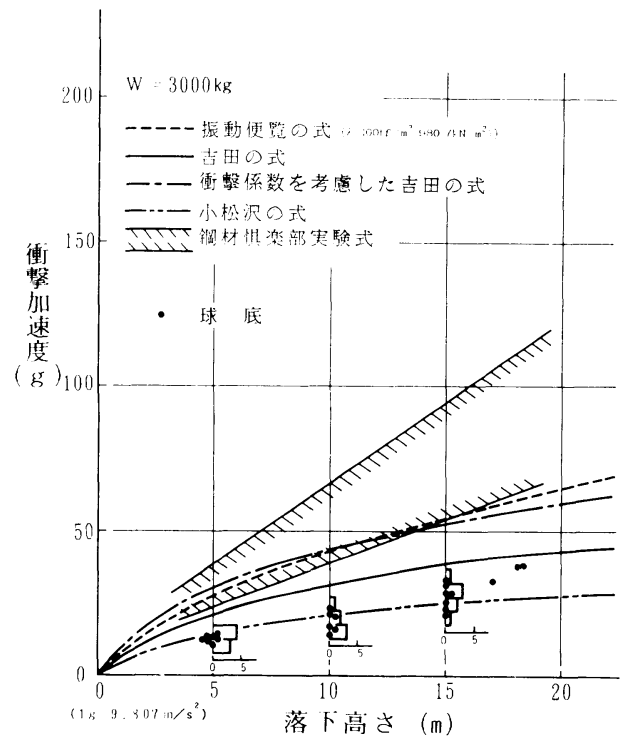

Fig. 9 Relationship between impulsive acceleration and falling heights $(3000 \mathrm{~kg})$.

\section{a ）重鍾加速度と貫入量}

重鍾質量が $1000 \mathrm{~kg}$ 球底について貫入量と衝撃加 速度の関係を示したものがFig. 10 である．同一落下高 さに対しても，貫入量と衝撃加速度の両方にかなりのば らつきが瑮められる。これは，主にサンドクッションの 状態に起因するものと考えられる。しかし，貫入量の増 加に伴い衝撃加速度が減少する傾向が認められる.

落下前の重鍾の位置エネルギーは衝撃力がサンドクッ ションに対して成す仕事に等しいとすると, 次式が成り 立つ。

$$
m g H=\int_{0}^{T_{0}} F(t) v(t) d t
$$

ここに， $m$ は重鍾の質量， $g$ は重力の加速度， $H$ は落 下高さ, $F(t)$ は時刻 $t$ におけるサンドクッションに作 用する衝撃力, $v(t)$ は時刻 $t$ における重錘の速度およ び $T_{0}$ は重鍾が静止するまでの時間である.

ここで, 上式が, 最大衝撃力 $F_{\max }=m \alpha_{\max }$ と貫入量 $\delta$ の積に比例すると仮定すると次式が得られる.

$$
\alpha_{\max }=c g \frac{H}{\delta}
$$

ここに，cは定数である.

Fig. 11 は衝撃加速度之（落下高さ／貫入量）の関係 を示したものである。図より，落下高さに関係なく，衝 撃加速度と（落下高さ／貫入量）の間に直線関係が認め られる。これより, 式（7）は衝撃力と貫入量の関係を 表わすのに妥当なものと考えられる。

b ）衝撃加速度とサンドクッション材の含水比

Fig.12は衝撃加速度とサンドクッション材の含水比の 関係を重鍾質量 $1000 \mathrm{~kg}$ の球底について落下高さ別に 示したものである.なお, 締め固め試験により得られた サンドクッション材の最適含水比は $20 \%$ であった。落

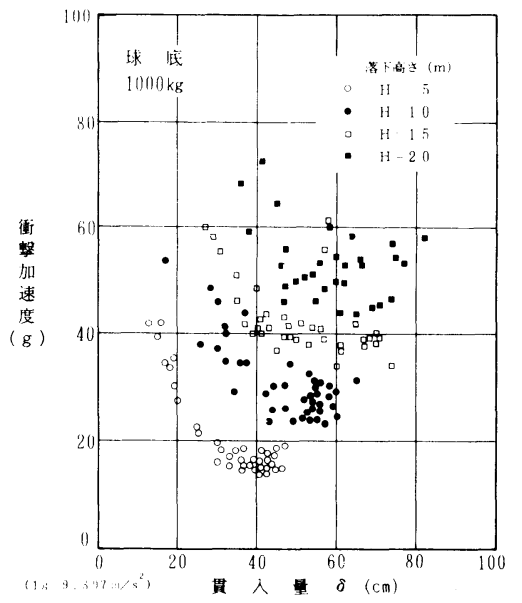

Fig. 10 Relationship between impulsive accelerations and penetrations. 


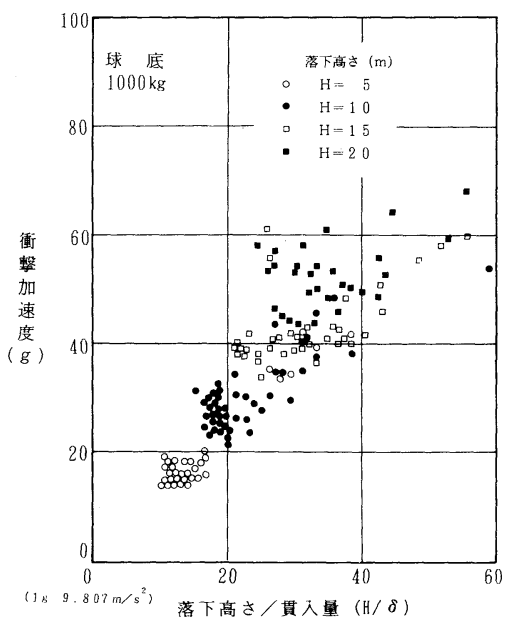

Fig. 11 Relationship between impulsive accelerations and ratios of falling height to penetration.
下高さが小さい範囲では，含水比が小さいほど衝撃加速 度は大きくなる傾向が認められるが，落下高さが $20 \mathrm{~m}$ の場合にはその傾向は明確でない，本実験は屋外で行っ たため最適含水比以下でのデータはなく，その点につい ての検討は行うことはできなかった。

c） コーン支持力と衝撃加速度

Fig. 13は，コーン支持力と貫入量の関係を重錘質量 $1000 \mathrm{~kg}$ の球底の重錘について落下高さ別に示したもの である. コーン支持力の増加に伴い貫入量の低下が明確 に認められる。

Fig. 14 は重量 $1000 \mathrm{~kg}$ の球底の重鍾の衝撃加速度と コーン支持力の関係を落下高さ別に示したものである.

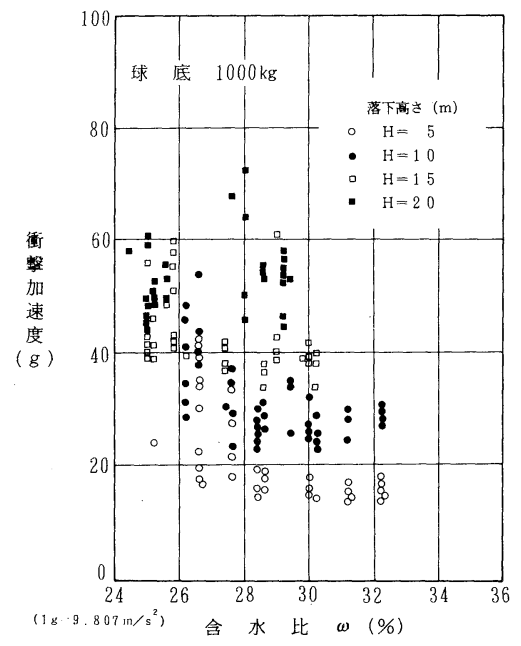

Fig. 12 Relationship between impulsive accelerations and moisture contents.

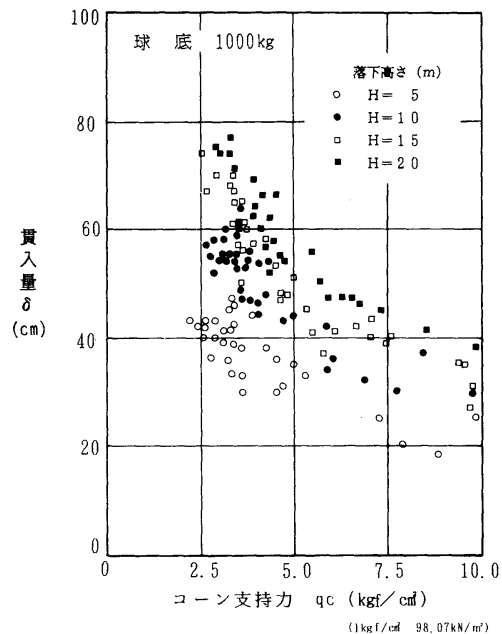

Fig. 13 Relationship between penetrations and cone bearing capacities.

コーン值の増加とともに衝撃加速度の増加が認められ る、すなわち，サンドクッション材の締め固めの程度が 大きく, 静的貫入抵抗が大きいほど衝撃加速度が大きく なることが認められる.

\section{（4）衝撃土圧}

以上の考察においては, 重鍾に発生する衝撃加速度の 測定値より重鍾がサンドクッションに与える衝撃力につ いて論じてきた。

しかし，落石覆い構造物が受ける衝撃力は，重鍾によ りサンドクッションが受ける衝撃力ではなく, サンド クッション中を伝播し，拡散してサンドクッションの底 部，すなわち，落石覆い構造物の屋根の表面に作用する

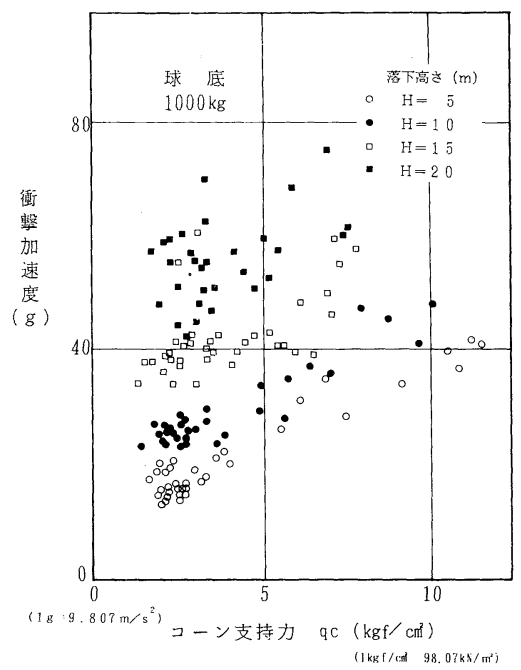

Fig. 14 Relationship between impulsive accelerations and cone bearing capacities. 
衝撃土圧である.

ここでは, サンドクッションの底部に設置した土圧計 により測定された土圧より落石覆い構造物に作用する衝 撃力を評価してみた。

a ）土圧分布の時間的変化

Fig. 15 (a) および (b) は，それぞれ，球底の質量 $1000 \mathrm{~kg}$ の平底占よび球底の重鍾を高さ $15 \mathrm{~m}$ から落下 させた場合の各位置における土圧の時間的変化を重鍾が サンドクッションに接触した瞬間から示したものである.

球底の落下点における土圧は，重鍾の衝突より 0.015 秒程度遅れて立ち上り，比較的緩やかな増加の後に最大 值を示し，その後，緩やかに減少している．落下中心よ り離れるに従い, 土圧の立ち上りは時間的に遅れ，かつ， 小さくなっており，その波形はより単調なものとなって いることが認められる.

平底の重鍾においても，落下点における土圧は球底の 重錘の場合と同様に，重鍾の衝突時より 0.015 秒程度遅 れて立ち上っており，最大值を示した後，多少の起伏を 示し，非常に緩やかに減少している．平底の重鍾の衝撃 加速度にみられた急激な波形の変化は，土圧では認めら れない.

Fig. 16は質量 $1000 \mathrm{~kg}$ の平底および球底の重錘を高 さ $15 \mathrm{~m}$ より落下させた場合の重鍾落下中心から半径方 向の衝撃土圧分布を土圧の立ち上り時間より 0.01 秒間 隔で示したものである。なお，土圧の測定点間はスプラ

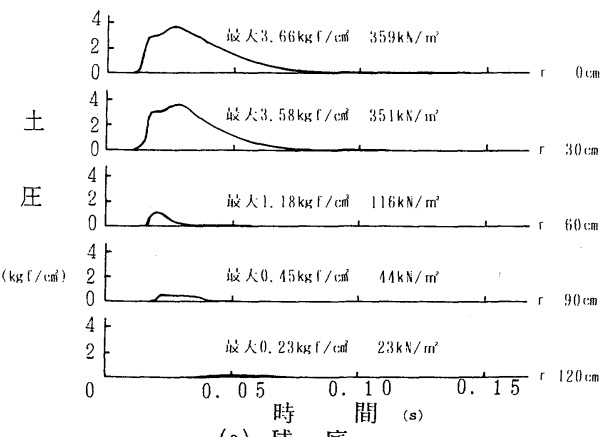

(a) 球 底

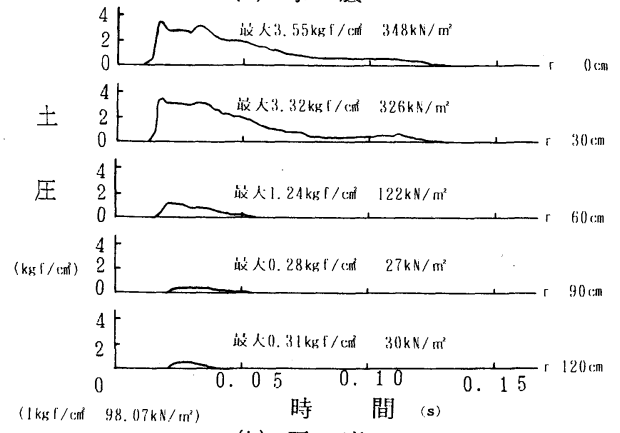

(b) 平 底

Fig. 15 Earth pressures at each point.
イン関数で補間してある.

最初，落下中心付近に発生する土圧は比較的短い時間 で半径方向に広く分布するようになり，その後，緩やか に分布域は減少している.

土圧の立ち上り時には，平底の重鍾による土圧の方が 球底の重鍾によるものより大きい.その後の土圧分布は, 落下中心付近では球底の重鍾の方が平底の重鍾より大き く，落下中心上り離れるに従って逆に，平底の重鍾の方 が球底より大きくなっている，その後，両者とも土圧は 小さくなっていくが，平底の重鍾による土圧は球底の重 錘によるものより大きい。

平底と球底の重鍾による土圧分布の時間的変化の観察 より, 各位置での土圧の最大值が同時に発生しないので, サンドクッションの底部で得られる全衝撃土圧は, 各位 置での最大土圧からは求まらず，時間的変化を考慮する 必要があると考えられる。

b ）土圧による衝撃力の時間的変化亡重錘の衝撃力

構造物に作用する時刻 $t$ の土圧による衝撃力 $P_{e}(t)$ は，土圧分布を軸対称と仮定すると，

$$
P_{e}(t)=2 \pi \int_{0}^{\infty} r P(r, t) d r
$$

と表わされる.ここに, $P(r, t)$ は重鍾の落下点中心か らの距離 $r$ における時刻 $t$ での土圧である.

Fig. 15 で示した実験結果より， $r=120 \mathrm{~cm}$ 以上では 土圧はほとんぼ発生していないので，積分範囲を $r=$ $120 \mathrm{~cm}$ までとした計算結果を以下に示す.

Fig. 17 (a) は質量 $1000 \mathrm{~kg}$ の球底の重鍾を高さ $15 \mathrm{~m}$ から落下させた場合について，重鍾の測定加速度から求 めた衝撃力および式（８）より得られた土圧による衝撃 力の時間的変化を示したものである. 土圧による衝撃力 は重鍾のサンドクッションへの衝突後約 0.15 秒遅れて 生じており，土圧による最大衝撃力は重錘の衝撃加速度 による最大衝撃力よりやや小さくなっている．重錘の加 速度より得られた衝撃力では, 2 つのピークを有するが, 土圧による衝撃力の時間的変化は単調である.

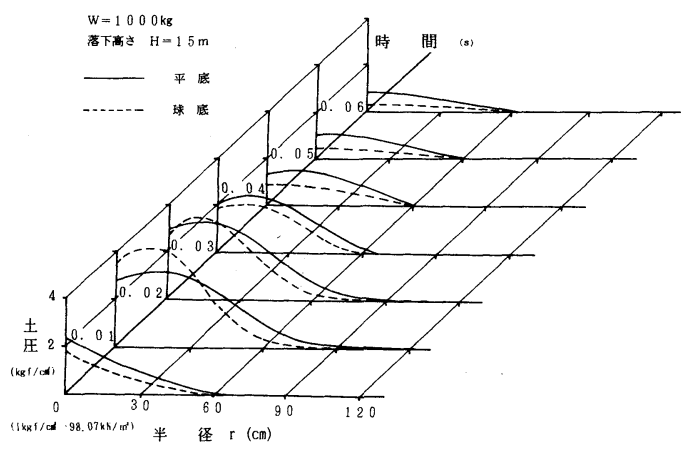

Fig. 16 Distributions of earth pressure. 


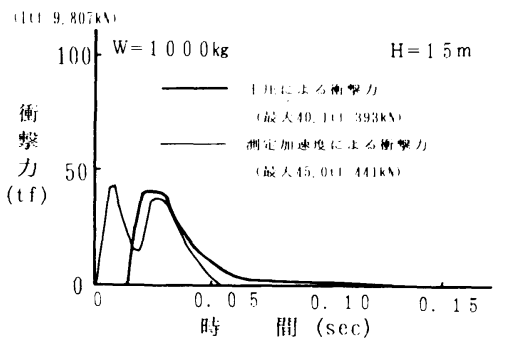

(a) 球 底

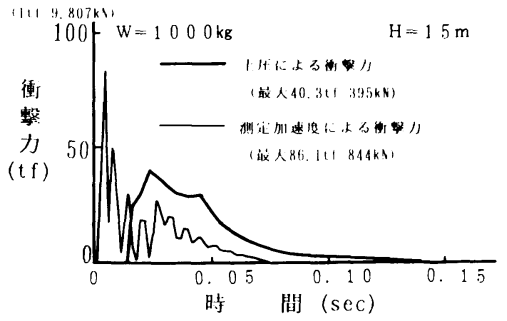

(b) 平底

Fig. 17 Impulsive load of integrated earth pressure.

球底の他のケースでも同様の傾向が認められており， 重錘の測定加速度より得られた最大衝撃力と土圧による 衝撃力の最大値はほぼ一致した。また, 錐底の重鍾にお いても球底の重鍾とほぼ同様な結果で，有意な差は認め られなかった。

Fig. 17(b)は質量 $1000 \mathrm{~kg}$ の平底の重鍾で, Fig. 17 (a) と同様に落下高さ $15 \mathrm{~m}$ の場合について, 重鍾の測定加 速度より得られた衝撃力および，土圧による衝撃力の時 間的変化を示したものである. 衝撃加速度より得られた 最大衝擊力はFig. 17 (a) に示した球底に比較して非常 に大きいが，土圧による衝撃力の最大値はその 2 分の 1 程度の大きさであり, 球底の場合とほぼ同じである，こ のことより, 平底の重錘より得られる衝撃加速度の鋭い ピークは, そのまま伝播されず, サンドクッション中で

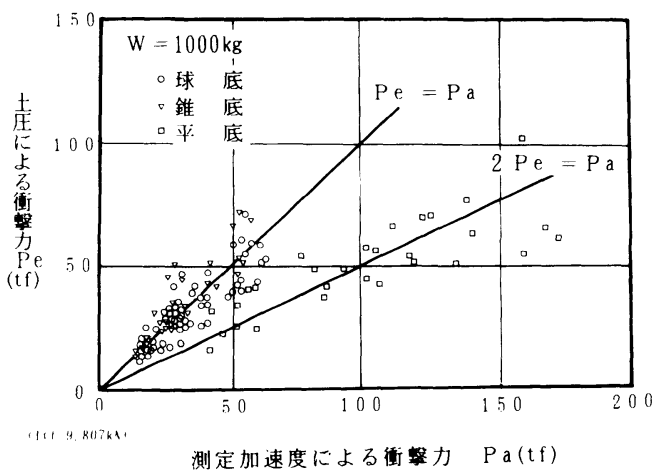

Fig. 18 Relationship between integrated earth pressures and impulsive forces of falling weight.
減衰しているものと推定される.

球底と平底の重鍾による全土圧波形の相違としては, 平底の重鍾による土圧による衝撃力は最大値に達した後 の減衰が緩やかであることである.

Fig. 18 は重鍾質量 $1000 \mathrm{~kg}$ の場合の测定最大加速度 より求まる最大衝撃力 $P_{a}$ と土圧による衝撃力の最大值 $P_{e}$ の関係を示したものである。これより，球底と錘底 の重鍾については, 測定最大加速度より求まる最大衝撃 力と土圧による衝撃力の最大值，すなわち，落石覆い構 造物に作用する衝撃力の最大值はほぼ等しいが, 土王に よる衝撃力の最大值は平底の重錘については, 測定衝撃 加速度より得られる最大衝撃力のほぼ 2 分の 1 となって いることがわかる.

Fig. 19 は, 質量 $1000 \mathrm{~kg}$ の球底, 錐底および平底の 重鍾を $5 \mathrm{~m}, 10 \mathrm{~m}, 15 \mathrm{~m}$ および $20 \mathrm{~m}$ から落下させたと きの土玨による最大衝撃力と落下高さの関係を示したも のである．平底の重鍾による衝撃力でも，他のものより やや大きい程度であり, 落石覆い構造物に作用する最大 衝撃力に及ぼす落石の形状の影響は，ほとんど認められ ないことがわかる.

\section{4. 結 論}

本研究においては, 落石がサンドクッション上に鉛直 落下する場合の衝撃加速度およびサンドクッション中を 伝播し，落石覆い構造物に作用する衝撃土圧およびその 分布を実験的に知るため, 高さ $24.8 \mathrm{~m}$ の落石実験用鉄 塔を建設し, 落石の質量および形状, 落下高さを変化さ せた数多くの実験を行った。

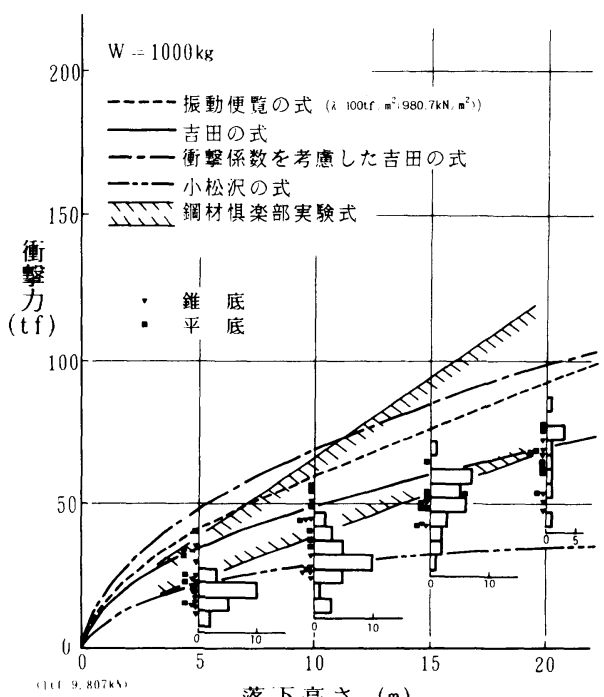

落下高さ (m)

Fig. 19 Relationship between integrated earth pressures and falling heights. 
その実験結果を検討した結果，以下の結論を得た。

（1）球底および錐底の重鍾の衝撃加速度の波形は比 較的滑らかな変化を示すが, 平底の重錘のものは, 鋭い 立ちトりとピーク後の鋸歯状の減衰を有している。

（2）球底と錐底の重錘における衝撃加速度はほぼ等 しく, 両者の差異は認められない, しかし, 平底の重鍾 より得られた衝撃加速度は他のものに比べて極端に大き い.

（3）重鍾質量の増加とともに衝撃加速度は減少す る.

（4）衝撃加速度は落下高さと貫入量の比に比例す る.

（5）サンドクッションがよく締め固まり，コーン支 持力が大きいほよ゙重錘の貫入量は小さく，衝撃力は大き (.

（6）重錘の衝撃力の高周波成分はサンドクッション 中で減衰する，球底および錐底の重錘による十圧分布は 落下点付近に集中する，平底の重錘によるものは比較的 広い範井に分布し，測定衝撃加速度にみられたような鋭 いピークは認められない。

（7）球底と錐底の重鍾では，土圧による衝撃力の最 大值は, 測定衝撃加速度による衝撃力の最大值とほぼ等 しい.

（８）平底の重鍾では，士珐による衝撃力の最大値は 重鍾の測定衝撃加速度による衝撃力の最大値の約 2 分の 1 程度の值であり, 球底および錐底による土圧による衝 撃力と同程度である。しかし，土王による衝撃力の時間 的変化は, 球底および錐底の土王による衝撃力とは異な り，最大值に達した後の減衰が緩やかである。

（９）士圧による衝撃力の最大值を落石覆い構造物に 作用する落石による衝撃力とすると，平底を含めたすべ ての実験值の上限を吉田の式で近似することができる.

（10）士王による衝撃力の時間的変化は重錘の形状に よって異なるが，これの落石覆い構造物に及ぼす動的効 果については, 今後の研究課題である.

なお，同一条件下での実験においても，测定結果には ばらつきが認められた。このばらつきの因子は数多く考 えられるが，落石覆い構造物の設計荷重の評価のために は,さらに数多くの実験を行い，これらの実験結果の統 計的な処理が必要であると考えられる. また, 実験結果
をできる限り忠実に表現できる解析法を開発することに より，奏際の落石覆い構造物への適用範囲も挔大する之 思われるが, 今後の研究課題である.

本研究のデー夕整理にあたり，金沢大学電子計算機七 ンターの FACOM M-170 F を使用した。

\section{参 考 文 献}

1) 高速道路調查会：落石防護施設の設置に関する調查研究 報告書, 高速道路調查会 (日本道路公由委託)，1974-2。

2）日本道路協会・道路防災施設調査特別委員会：道路防災 施設調查報告書，日本道路協会，道路防災施設調查特別 委員会, 1980-3

3）日本鉄道施設協会：落石対策の手引一日本国有鉄道施設 局上:木課編, 日本鉄道施設協会, 1978-3.

4) 日本道路協会：落石対策便覧, 日本道路協会, 1983-7.

5）上:木学会：土木技術者のための振動便覧，pp. 320 324, 1966.

6）鋼材俱楽部：新しい落石覆いの開発に関する研究，鋼材 俱楽部, 研究報告書, 1973-4.

7）吉田 博・石塚賢吉・細川 豊：ロックシェッドの落不 による衝撃力の推定に関する実験, 道路, pp. 35〜41, 1976-10.

8）建設省士:木研究所動士:質研究室：敷砂上:落石の衝撃力 に関する実験報告書，也木研究資料，1822 号，1982-3.

9）吉田 博・桝谷 浩・鈴木梊次・岡 衛・永木卓美：茾 ンドクッショントへの落石の衝撃力とその伝播について, 第 1 回落石の衝撃力およびロックシェッドの設計に関す るシンポジウム論文集, pp. 1 8，1983-7.

10）吉田 博・㭮谷 浩・岡 衛：落石の衝撃力の推定実験 およびその結果の考察について，第 38 回土木学会年次学 術講演会講演概要集, 第四部門, pp. 351 352，1983-9.

11）吉田 博・桝谷 浩・鈴木哲次：落石の衝撃加速度之 ロックシェッドへの作用衝撃力について, 第 38 回土木学 会年次学術講演会概要集, 第 III部門, pp. $353 \sim 354$, 1983-9

12）園田恵一郎・小林治俊・鈴木輝男：ロックシェッドに対 する落石荷重計算法 (ヘルツ式の改良)について, 第 1 回落石の衝撃力およびロックシェッドの設計に関するシ ンポジウム論文集, pp. 25〜35, 1983-7.

13）金沢大学工学部土木工学科構造力学研究室：敷砂上への 落石実験報告書, 1983-12.

14）和保達美・赤沢 稔：鉄道上木施丁.法講座, pp. 263一 $271,1963$.

(1983.12.19 • 受付) 